\title{
Article
}

\section{Stretching the Joint Criminal Enterprise Doctrine to the Extreme: When Culpability and Liability Do Not Match}

Perova, Natalia

Available at http://clok.uclan.ac.uk/15910/

Perova, Natalia (2016) Stretching the Joint Criminal Enterprise Doctrine to the Extreme: When Culpability and Liability Do Not Match. International Criminal Law Review, 16 (5). pp. 761-795. ISSN 1567-536X

It is advisable to refer to the publisher's version if you intend to cite from the work. http://dx.doi.org/10.1163/15718123-01605003

For more information about UCLan's research in this area go to http://www.uclan.ac.uk/researchgroups/ and search for <name of research Group>.

For information about Research generally at UCLan please go to http://www.uclan.ac.uk/research/

All outputs in CLoK are protected by Intellectual Property Rights law, including Copyright law. Copyright, IPR and Moral Rights for the works on this site are retained by the individual authors and/or other copyright owners. Terms and conditions for use of this material are defined in the policies page. 


\title{
Stretching the Joint Criminal Enterprise Doctrine to the Extreme: When Culpability and Liability Do Not Match
}

\begin{abstract}
Joint criminal enterprise (JCE) has caused a lot of concern amongst international criminal law practitioners and academics since its first appearance at the ad hoc Tribunals. A recent landmark decision, by the UK Supreme Court in Jogee, that overruled 30 years of common law development on joint enterprise, stimulates further discussions on whether JCE in its current form fairly reflects the balance between culpability and corresponding liability of the defendant. This article explores this issue by suggesting that the level of culpability of defendants does not match the degree of liability they incur under JCE III. The article dissects the JCE III mode of liability by considering it a 'two-crime liability': a common purpose crime and a foreseeable crime, and compares it with aiding/abetting. This article argues that the level of culpability of defendants under JCE III is much lower than their liability for the crimes they are convicted of.
\end{abstract}

\section{Keywords}

international criminal law; ad hoc Tribunals; ICTY; joint criminal enterprise; aiding and abetting; modes of liability; culpability; accessory

\section{Introduction}

With most of the trials being completed, and only a few still being considered by the Trial and Appeals Chambers of the International Criminal Tribunal for the former Yugoslavia ('ICTY'), the doctrine of Joint Criminal Enterprise ('JCE') remains widely criticised. This mode of liability, developed by the Tadić case and elaborated in subsequent cases, continues to pose many questions. This can affect the persuasiveness of the ad hoc Tribunals' jurisprudence (i.e. ICTY, International Criminal Tribunal for Rwanda (ICTR) and United Nations Mechanism for International Criminal Tribunals (MICT)) and their legacy for existing and future institutions of international criminal justice.

Despite consistent approval of the JCE doctrine and its extended form (so-called JCE III) by the ICTY and ICTR Appeals Chamber, defence teams consistently raise objections to the existence and 
application of JCE, ${ }^{1}$ although these objections are consistently dismissed by the Chambers. ${ }^{2}$ Both the Special Tribunal for Lebanon ('STL') and Extraordinary Chambers of the Courts of Cambodia ('ECCC') expressed their criticism of the extended form of JCE doctrine. ${ }^{3}$ The ECCC did not recognise the customary status of JCE III for its cases, ${ }^{4}$ and the STL denied the possibility of application of JCE III to specific intent crimes. ${ }^{5}$ The recent landmark decision in the Jogee case by the UK Supreme Court, ${ }^{6}$ effectively overruled the existence of liability under joint enterprise (where a foresight had been sufficient mens rea to be convicted in murder as an accessory). This further undermined the foundations of JCE doctrine, especially its extended form. This case and its significance for the development of JCE doctrine by the ICTY will be further explored in this article. Academic opinion is split regarding the legitimacy of JCE doctrine, in particular in relation to its extended form. Some authors put forward powerful arguments to support the position maintained by the ICTY and ICTR Chambers that JCE III mode of liability is valid and necessary to bring to justice those who commit large-scale international crimes. ${ }^{7}$ These authors argue that, due to the collective nature of the international crimes, public policy demands the prosecution of the members of JCE III to protect society from those who come together to commit crimes. ${ }^{8}$ They argue that despite the fact that participants in JCE III may not have intention to commit extended crimes, those crimes are rendered possible by their participation in JCE III and, in any event, the defendants' participation can

\footnotetext{
${ }^{1}$ See for instance, Defence Appeal Brief in the Tolimir case, Case No. IT-05-88/2-A, paras. 53-64; Prosecutor v. Tolimir, Case No. IT-05-88/2-A, Judgement, 8 April 2015, ('Tolimir Appeal Judgement'), paras. 275-276; Đorđević Appeal Brief, paras. 20-77, challenging the existence of JCE under customary international law; see also Prosecutor v. Đorđević, Case No. IT-05-87/1-A, Judgement, 27 January 2014, ('Đorđević Appeal Judgement'), para. 25. In relation to application of JCE III to specific intent crimes, see Beara's Appeal Brief in the case of Prosecutor v. Popović et al., Case No. IT-0588-A, Judgement, 30 January 2015, ('Popović et al. Appeal Judgement'), para. 292-302, Miletić Appeal Brief, paras. 353358; see also Popović Appeal Judgement, paras. 1437, 1671, 1704.

2 The main reasons for dismissing the objections were the consistency of practice of the Tribunal in relation of the existence and interpretation of JCE; its solid grounding in customary international law as shown by Tadić; the failure of the accused to provide a cogent reason for the Appeals Chamber to depart from its consistent jurisprudence. See for instance, Tolimir Appeal Judgement, para. 281; Popović et al. Appeal Judgement, paras. 1672-1673; Đorđević Appeal Judgement, paras. 41, 49, 58. In relation to the application of JCE III to specific intent crimes, see Popović Appeal Judgement, paras. 1440, 1707-1708; Prosecutor v. Stakić, Case No. IT-97-24-A, Judgement, 22 March 2006, ('Stakić Appeal Judgement'), para. 38, referring to Prosecutor v. Brđanin, Case No. IT-99-36-A, Decision on Interlocutory Appeal, 19 March 2004, ('Brđanin JCE III Appeal Decision'), paras 9-10. See Đorđević Appeal Judgement, paras. 58, $77,83,829$.

3 JCE III, or extended form of JCE, consists of the same actus reus as JCE I (basic form), but the mens rea requirement is different: a foreseeability of the risk that the additional crime might be committed and that the defendant willingly took that risk (see Tadic Appeal Judgement, para. 227).

${ }^{4}$ See Case File/Dossier No. 002/19-09-2007/ECCC/TC, Decision on the Applicability of Joint Criminal Enterprise, 12 September 2011, para. 38; see also File/Dossier No. 002/19-09-2007-ECCC/OCIJ (PTC38), Decision on the Appeals against the co-investigative judges' order on joint criminal enterprise (JCE), 20 May 2010 for a more detailed analysis of the customary international law status of JCE III liability, in particular paras. 77, 88.

${ }^{5}$ STL Decision, paras. 248-249.

${ }^{6} R$ v. Jogee [2016] UKSC 8; Ruddock v. the Queen [2016] UKPC 7 ('Jogee case').

${ }^{7}$ See for example A. Cassese, M. De Ming Fan, V. Thalmann, S. Zappala, 'Amicus curiae brief of Professor Antonio Cassese and members of the Journal of International Criminal Justice on joint criminal enterprise doctrine', 20 Criminal Law Forum (2009) 289, pp. 326-329, A. Cassese, 'The proper limits of individual criminal responsibility under the doctrine of joint criminal enterprise', 5 Journal of International Criminal Justice (2007) 109, pp. 117-122.

${ }^{8}$ Ibid.
} 
be addressed at the sentencing stage. ${ }^{9}$ This article provides an opposing view to this position and argues against these arguments, proposing a different interpretation of the JCE III doctrine.

Other authors express their criticism of the JCE doctrine, referring back to the foundations of the JCE doctrine in the Tadić case, and conducting further analysis and interpretation of customary international law on JCE doctrine. ${ }^{10}$ This article does not propose further to analyse the JCE doctrine but aims to analyse the JCE III doctrine in its current form, which has expanded over the years of the ad hoc Tribunals' jurisprudence. The article examines the issues of the JCE III doctrine from a new angle of the relationship between culpability and liability. It shows, from both a conceptual and logical perspective, that the JCE III in its current form is not sustainable for the purpose of the fair conviction of the accused in international crimes.

There are some authors, who consider that the JCE III mode of liability contradicts the principle of culpability. ${ }^{11}$ Although persuasively explaining their position, they do not go into the essence of the relationship between culpability and liability. Whilst Robinson considers in more detail the principle of culpability on a theoretical level and provides examples where the JCE III liability does not comply with this principle, ${ }^{12}$ this article goes further than that. It examines each element of JCE III liability, compares it with aiding/abetting and provides a new argument against maintaining the current, overstretched, version of JCE III mode of liability.

In addition, this article proposes a new conceptual perspective to analyse the JCE III doctrine, considering the JCE III mode of liability as a two-crime liability: the first being the common purpose crime and the second being a foreseeable, or extended, crime, which the defendant is charged with. It proceeds with an argument that only the culpability for the second crime is relevant for the JCE III liability, as this is the crime the person is actually charged with under JCE III. The article compares JCE III with aiding/abetting to interpret the degree of liability involved in JCE III and the level of culpability attached to it.

The article also provides a new way of approaching and challenging the possibility of application of JCE III liability to specific intent crimes, not based on traditional customary international law

\footnotetext{
${ }^{9}$ Ibid.

10 See for instance, S. Powles, 'Joint criminal enterprise: criminal liability by prosecutorial integrity and judicial creativity', 2 Journal of International Criminal Law (2004) 606, pp. 615-617; M.G. Karnavas, 'Joint criminal enterprise at the ECCC: a critical analysis of the pre-trial chamber's decision against the application of JCE III and two divergent commentaries on the same', 21 Criminal Law Forum (2010) 445; M. Sassòli, L. M. Olsen, 'The Judgement of the ICTY Appeals Chamber on the merits in the Tadić case. New Horizons for international humanitarian and criminal law?' 82 International Review of the Red Cross (2000) 733; J. S. Martinez, A. M. Danner, 'Guilty associations: joint criminal enterprise, command responsibility, and the development of international criminal law' 93 California Law Review (2005) 75 , pp. $110-120$.

11 See for example, K. Ambos, 'Joint criminal enterprise and command responsibility', 5 Journal of International Criminal Justice (2007) 159, p. 173; H. Olasolo, 'Joint criminal enterprise and its extended form: a theory of coperpetration giving rise to principal liability, a notion of accessorial liability, or a form of partnership in crime?', 20 Criminal Law Forum (2009) 263, p. 285; D. Robinson, 'The identity crisis of international criminal law', 21 Leiden Journal of International Law (2008) 925, pp. 939-942.

${ }^{12}$ Robinson, ibid., pp. 939-942.
} 
arguments, but rather on the logic and on the culpability. It explores the contention that there is a mismatch between the level of culpability and the degree of liability and that the law on JCE should be clarified to make them coincide. This might reduce the sense of injustice caused by a too opportunistic expansion of JCE III, especially in relation to the specific intent crimes, and make the Tribunals' jurisprudence more coherent. This existing sense of injustice is evidenced by the constant arguments against the application of the JCE III doctrine by the defence counsel despite clear pronouncements by the Chambers in this regard. This illustrates non-acceptance by the defence of the logic of JCE III and the need to review this question. The jurisprudence of the STL and ECCC also confirms this point. Therefore, this article will proceed with the analysis of JCE III liability with the aim of suggesting further clarifications and revisions to this doctrine.

Finally, JCE III has been proved to be most controversial in its application to 'specific intent' crimes (e.g. genocide, persecution) due to the higher threshold of the mens rea that needs to be proven for those crimes to be committed. ${ }^{13}$ This article explores the culpability/liability balance with a particular emphasis on the convictions under JCE III of specific intent crimes. The article will firstly consider the theoretical foundation of the relationship between the culpability and liability. Then it will be explored where the liability for JCE stands in terms of the seriousness of the illegal conduct and the consequences of that. For these purposes, the liability under JCE will be compared with the liability for the actual perpetration and liability for aiding and abetting.

\section{Defining the Relationship between Culpability and Liability under the JCE Doctrine on a Theoretical Level}

The purpose of this section is to define the notions of culpability and liability in the way they will be understood in this article. The relationship between the culpability and liability will be further explained and analysed in order to provide a theoretical basis for the main contention discussed in this article.

The main contention in this article is that the JCE in its extended form provides for an overly extensive liability for the crimes that the defendant has a tenuous connection to, which does not reflect the degree of their culpability for those crimes. This contention is also based on the principle of personal culpability (nulla poena sine culpa), which was referred to in Tadić as 'the foundation of criminal

\footnotetext{
${ }^{13}$ See for instance, the challenged by the defence team in Beara's Appeal Brief in the case Popović et al., paras. 292-302, see also Popović Appeal Judgement, paras. 1437, 1440; see also I. Bantekas, International Criminal Law (4 ${ }^{\text {th }}$ ed., Hart, Oxford, 2010), p. 57; E. van Sliedregt, 'Joint criminal enterprise as a pathway to convicting individuals for genocide', 5 Journal of International Criminal Justice (2007) 184, p. 190; E. van Sliedregt, Individual Criminal Responsibility in International Law (Oxford University Press, Oxford, 2012), p. 142.
} 
responsibility. ${ }^{14}$ Under this principle, persons should be held responsible only for their own conduct. It also requires sufficient mens rea in relation to their own conduct. ${ }^{15}$ As the discussion of the main issue is based on the analysis of the relationship between culpability and liability under the JCE III doctrine and the notions of liability and culpability are used in different contexts and have different meanings, ${ }^{16}$ they should be defined for the purposes of this article.

The notion of culpability in this article is understood in a more general sense, as a moral culpability or blameworthiness of a person, ${ }^{17}$ which takes into account the extent of their actual involvement to the crime, which they are accused of, and any actions and considerations that led this crime to happen. ${ }^{18}$ Therefore, this category encompasses what the person actually did or the state of mind they actually had rather than what the law says/identifies they did. The concept of liability is understood in this article to mean the identification of the person's action by law as falling into a defined legal category, ${ }^{19}$ which would incur particular legal consequences for the person for their actions.

The finding of liability (person's guilt) will normally lead to a punishment. The mode of liability and the type of crime will determine (together with other aggravating/mitigating factors) the degree of punishment, or sentence, of the person. Therefore, the liability of a person determines whether or not the punishment will be imposed and what sort of punishment it will be. Similarly, the culpability, as opposed to liability, of the person may be taken into account only at the sentencing stage (if at all) when all factors are considered together with the harm that the crime has caused.

Given the role of liability in determination of whether to impose a punishment, it is very important that the level of culpability and liability match. ${ }^{20}$ Otherwise, if they do not, this will violate the principle of fair labelling by not taking into account the correct level of person's culpability in assessing the person's involvement in the crime. ${ }^{21}$

\footnotetext{
${ }^{14}$ Tadić Appeal Judgement, para. 186.

${ }^{15}$ Robinson, supra note 11 , p. 926.

${ }^{16}$ See for example K. Ambos, 'Remarks on the General Part of International Criminal Law', 4 Journal of International Criminal Justice (2006) 660, p. 667, talking about a normative concept of liability, where culpability shows not only intent to cause a certain result, but also the blameworthiness of the perpetrator's conduct. See also M. S. Moore, 'Intention as a marker of moral culpability and legal punishability', in R.A. Duff, S. Green, Philosophical foundations of criminal law (Oxford University Press, Oxford, 2011), pp. 183-184, discussing different meanings of culpability, including culpability being a synonym of mens rea requirements.

${ }^{17}$ See also Moore, ibid., p. 183.

${ }^{18}$ See also Ambos, supra note 11, p. 173, stating that 'culpability implies personal conduct, which finds expression in individual contributions to the enterprise, contributions that do not necessarily correspond to the function assigned to the accused in the enterprise.'

${ }^{19}$ See also Moore, supra note 16, p. 182.

${ }^{20}$ See also J.D. Ohlin, 'Joint intentions to commit international crimes', 11 Chicago Journal of international Law (2010) 693, pp. 750-751, talking about the importance of the criminal law doctrines codifying different levels of culpability. See also M. Osiel, 'The banality of good: aligning incentives against mass atrocity', 105 Columbia Law Review (2005) 1751, p. 1772, stating that the ICTY approach to JCE 'increasingly lures international law to a point where liability threatens to exceed the scope of moral culpability.'

${ }^{21}$ See also Ohlin, ibid, p. 751 for the discussion on fair labelling. See also Robinson, supra note 11, pp. 927, 941-942. See also Jogee case, para. 74.
} 
The principle of fair labelling concerns the 'labelling' of offender's conduct in relation to the crime in question and reflects the wrongfulness and severity of the conduct. ${ }^{22}$ It is considered a fundamental principle of criminal law. ${ }^{23}$ It is particularly relevant given that this principle considers the level of participation of the defendant in the crime taking into account the essence and the totality of the criminal conduct in issue ${ }^{24}$ when considering JCE III liability as a form of commission. A person convicted in genocide under JCE III liability would be held to have 'committed' or be a perpetrator of genocide (not simply have assisted genocide), despite having sometimes a very low level of culpability or involvement in the crime itself. ${ }^{25}$ In this way, this conduct would not be labelled fairly to reflect the real degree of wrongfulness of the conduct.

Furthermore, if the level of culpability does not coincide with the high degree of liability, this can also contribute to a sense of injustice. ${ }^{26}$ If the culpability is higher than the liability, the victims may feel injustice, as those, who were blameworthy for the committed crimes, would be left unpunished. For example, if the person is acquitted due to a gap in law, but their role in the crime was substantial, the victims may feel that the person should have been punished. If the level of culpability is lower than the degree of liability, this would mean the injustice for the defendants, as those, who had very low or almost no involvement in the crime, may be unduly punished, or the punishment imposed will be disproportionate to their actual conduct. That could particularly apply to those who have not directly perpetrated the crime, but whose involvement was proved through various modes of liability (e.g. accessory liability). They may receive a similar (or higher) sentence for completely different conduct with a low level of involvement in the crime.

This sense of injustice may further lead to a distrust of the justice system by people who perceive this injustice and, subsequently, to the dismissal of the system as a whole. ${ }^{27}$ Therefore, in order to avoid the injustice that can be generated by the international justice system, it is important to see whether the liability imposed by law matches the culpability of persons involved in the crimes.

\footnotetext{
${ }^{22}$ See E. van Sliedregt, 'The Curious case of international criminal liability,' 10 Journal of International Criminal Justice (2012) 1171, p. 1184; D. Nersessian, 'Whoops, I Committed Genocide! The Anomaly of Constructive Liability for Serious International Crimes,' 30 Fletcher Forum of World Affairs (2006) 81, p. 96.

${ }^{23}$ See Nersessian, ibid, p. 96; M. Granik, 'Indirect perpetration theory: a defence,' 28 Leiden Journal of International Law (2015) 977, p. 990.

${ }^{24}$ See Nersessian, supra note 22, p. 96.

${ }^{25}$ On this point, see also Nersessian, supra note 22, p. 98, Robinson, supra note 11, pp. 941-942.

${ }^{26}$ In fact, K. Ambos suggests that the principle of culpability will be violated by the JCE III doctrine, if the defendant's lower contribution under JCE III is not taken into account at the sentencing stage, which was in turn expressly rejected by the ICTY Appeals Chamber (see Ambos, supra note 11, pp. 173-174). However, that does not include the concern of the violation of the principle of fair labelling.

${ }^{27}$ The fact that JCE III was challenged by many defence teams and continue to be challenged, despite the fact that the jurisprudence of the ICTY/ICTR is now more settled on this point.
} 

JCE Follow the Fate of Its Counterpart in English Law Post Jogee Case?

Whilst the international criminal law doctrine of JCE, in particular its extended form, continues to be a subject of serious criticism from defence lawyers and academics, its counterpart in English common law - joint enterprise - sustained some serious changes and was almost defeated by the UK Supreme Court judges after almost thirty years of continuous development.

In its recent judgement of 18 February 2016 (by coincidence, the day when it was publicly announced that the long overdue judgement in the famous Karadžić case would be delivered), the UK Supreme Court unanimously held in the Jogee case that, for the accessory liability in murder, the mens rea requirement is not foresight, but an intent to encourage or assist the principal in killing or causing grievous bodily harm, and a foresight of the crime is only evidence from which the jury could potentially infer the necessary intent. ${ }^{28}$

If a similar pronouncement had been made by the ICTY Appeals Chamber, it would essentially have 'killed' the extended form of JCE - JCE III, as the existence of foresight rather than direct intent is the essential distinction between JCE III and JCE I. Although it was a domestic court which overruled the existence of the joint enterprise liability on the basis of the foreseeability of the consequences of the common plan, the importance of the Jogee case for international criminal law doctrine is very high. This is because the JCE doctrine is believed to have its origins in the common law doctrine of joint enterprise. ${ }^{29}$

It is important to recognise that the JCE doctrine developed in the Tadic case was based on several jurisdictions, ${ }^{30}$ including a number of common law jurisdictions. ${ }^{31}$ However, it is equally important to understand that the UK Supreme Court in the Jogee case essentially overruled the 30 years of the jurisprudence developing the joint enterprise liability, established by the case of Chan Wing-Siu v. The Queen [1985] AC 168 by the Privy Council. ${ }^{32}$ Had the judges of the Privy Council interpreted correctly the mens rea of joint enterprise from the start, the joint enterprise doctrine in common law jurisdictions might not have developed in such a way as for foresight to be sufficient mens rea for liability for murder of those defendants who do not carry out the actus reus of the crime, unless they had full intent to kill or cause grievous bodily harm $(\mathrm{GBH})$.

\footnotetext{
${ }^{28}$ Jogee case, para. 87.

${ }^{29}$ See for example, J. D. Ohlin, 'Organisational criminality,' in E. van Sliedregt and S. Vasiliev (eds.), Pluralism in international Criminal Law (Oxford University Press, Oxford, 2014), p. 108.

${ }^{30}$ See Prosecutor v. Tadić, Case No. IT-94-1-A, Judgement, 15 July 1999, ('Tadić Appeal Judgement'), para. 224, referring to such jurisdictions as Germany, Netherlands, France, Italy.

${ }^{31}$ See Tadić Appeal Judgement, para. 224, also referring to jurisdictions of England and Wales, Canada, the United States, Australia, Zambia.

${ }^{32}$ See Jogee case, paras. 3, 86-87.
} 
Notwithstanding the potential consequences for common law jurisdictions in relation to their development of joint enterprise jurisprudence, at least some basis for the ICTY jurisprudence on JCE III liability may have been removed now, namely its reliance on English law. In relation to the law of England and Wales, the Tadić Appeals Chamber relied on three cases to support the introduction of JCE III liability: $R$ v. Anderson; Morris [1966] 2 QB 110; $R$ v. Hyde [1991] 1 QB 134; Hui ChiMing v. The Queen [1991] 3 All E.R. 897. The latter two cases expressly relied on the ruling in Chan Wing-Siu v. The Queen, which was overruled in Jogee, and therefore these two cases can no longer stand as authorities for English law. The other decision ( $R$ v. Anderson; Morris) relied upon by Tadić does not support the existence of JCE III doctrine as it excludes the liability of a secondary offender for the acts, which went beyond what had been agreed as part of the joint enterprise, i.e. unauthorised acts. $^{33}$

What the Supreme Court appears to be saying in Jogee is that there is no space for the 'parasitic' form of joint enterprise in English law jurisdiction, which originally formed part of accessory liability. ${ }^{34}$ The Court held that it is not sufficient to prove the foresight of the crime going beyond criminal purpose, although the foresight can be regarded as evidence of intent. ${ }^{35}$ As long as there is an intent to encourage or assist the commission of the crime, that should be sufficient to hold the secondary party liable for the offence together with the principal. ${ }^{36}$ That follows from the fact that there is no need for a prior agreement to commit a crime to be proved ${ }^{37}$ and a positive intent to commit the crime itself (as opposed to the intent to assist or encourage the commission) is not needed. ${ }^{38}$

The Supreme Court changed the role of foresight from being a threshold for mens rea under joint enterprise liability to it constituting mere evidence to prove the intent. This is a welcomed outcome from the culpability point of view. By upgrading the mens rea requirement from foreseeability to direct intent, the Supreme Court, in effect, allowed future jurors to find not guilty those who foresaw that a murder can be committed but did not intend that outcome. With foresight being mere evidence of intent, the jury can (but does not have to) find that a direct intent was present and the person (satisfying other requirements) is guilty. They may also consider that the foresight does not show

\footnotetext{
${ }^{33}$ The Tadić Appeals Chamber surprisingly quoted only a part of the ratio decidendi of the Anderson/Morris case, namely 'where two persons embark on a joint enterprise, each is liable for the acts done in pursuance of that joint enterprise, that that includes liability for unusual consequences if they arise from the execution of the agreed joint enterprise,' omitting to continue the sentence: 'but (...) if one of the adventurers goes beyond what has been tacitly agreed as part of the common enterprise, his co-adventurer is not liable for the consequences of that unauthorised act.' Curiously, the omitted part goes against the existence of JCE III, rather than for its support. Furthermore, the liability in question of the secondary offender in that case was for the manslaughter, not murder, and therefore a full intent to kill (or cause GBH) was not required. Thus, this case cannot be used to justify the reduction of mens rea requirement to foreseeability standard for the purposes of JCE III.

${ }^{34}$ See D. Ormerod, K. Laird, Smith and Hogan's Criminal law (14 ${ }^{\text {th }}$ ed., Oxford University Press, Oxford, 2015), pp. 243, 259. See also Jogee case, paras. 78, 95.

${ }^{35}$ Jogee case, paras. 83, 87 .

${ }^{36}$ Ibid., para. 95.

${ }^{37}$ Ibid., paras. $78,95$.

${ }^{38}$ Ibid., para. 10.
} 
intent in particular circumstances, whereas, when foresight was considered sufficient mens rea, the jury (or any other trier of fact) has no choice but to find the person having the sufficient mens rea for the crime, if the foresight was proved.

There are several reasons why the UK Supreme Court decided to depart from the previously existing approach. One of these is that the liability for encouraging or assisting achieves the same result allows a secondary party (who is not the direct perpetrator of the crime) to be convicted alongside with the principal. ${ }^{39}$ Secondly, the Court stated that there may often be no practical distinction between an intention to assist someone to commit crime and intent to commit the crime. ${ }^{40}$ Therefore, the mens rea required for a secondary party to be convicted, namely, the intent to assist or encourage, seems to be of the same degree as the direct intent to commit the crime.

Furthermore, the UK Supreme Court considered that if foresight is still considered to be sufficient mens rea for the conviction of a secondary party in murder, this would lead to 'the striking anomaly', as there will be a lower mental threshold for the accessory to be convicted in comparison with the principal, ${ }^{41}$ and therefore, the accessory will have a lower level of culpability. ${ }^{42}$

The question, however, is whether the recent English law development of joint enterprise liability should be taken into account by the ICTY Chambers in their consideration of JCE III liability. It is argued in this article that it should be. With two cases remaining on trial (one on re-trial) and some cases on appeal at ICTY and MICT (using the ICTY and ICTR previous jurisprudence), it is important that the problem with the JCE doctrine is recognised. This is important for the legacy of the ad hoc Tribunals and for the future development of international criminal law, which takes into account the Tribunals' jurisprudence. Furthermore, the defendants, whose cases are still being considered by the Tribunals, would certainly consider it to be important as their liability for the crimes charged under the JCE III umbrella and their sentences are still at stake. If the English law development of joint enterprise in Jogee is taken into account, they may be convicted on lesser number of counts or receive lower sentence. Apart from the origin of the JCE III doctrine, the decision in the Jogee case provides for an example of a turn the JCE III should take on its route to get closer to the point where the level of culpability and the degree of liability would coincide.

It is recognised that the ICTY judges deal with different scales of crimes committed under the umbrella of JCE liability. International crimes are usually much more complex and there may be several JCEs alleged in one case. ${ }^{43}$ The criminal purpose encompassing crimes to be committed can

\footnotetext{
${ }^{39}$ Ibid., para. 88.

${ }^{40}$ See ibid., para. 90.

${ }^{41}$ Jogee case, para. 84.

${ }^{42}$ Ibid., para. 83 .

${ }^{43}$ See for example, Prosecutor v. Karadžić, Case No.: IT-95-5/18-T, Judgement ('Karadžić Trial Judgement'), 24 March 2016; Prosecutor v. Popović et al, Case No.: IT-05-88-T, Judgement ('Popović Trial Judgement'), 10 June 2010.
} 
be very broadly formulated (e.g. to forcefully remove Bosnian Muslims from a particular territory). ${ }^{44}$ Given how broad the common criminal purpose can be, there may be a lot of different crimes committed within the purpose or beyond (including foreseeable crimes) - murder, genocide, sexual offences, damage to property, etc.

In order to consider the liability of those high-ranking officials who participated in the formulation of this criminal purpose (and, very often, not in its execution), the Chambers often take into account the evidence of their awareness of the purpose itself through their position in the hierarchical political or military structure ${ }^{45}$ and whether they were informed about the crimes or orders to commit their crimes. ${ }^{46}$ The major factor for their liability is how much they knew about what was going on on the ground. Given that, it is much more difficult to prove the direct intent to commit the crimes than the foreseeability of those crimes to be committed. However, that opens the possibility still to convict the high-ranking officials in aiding and abetting the crimes, without the need to have recourse to JCE, akin to the English law post-Jogee. That will allow an anomaly, highlighted in Jogee, where the culpability of the accessory is of a lesser degree than of the principal, despite the principal performing the actus reus of the crime. ${ }^{47}$

The latter point will be further explored from the point of view of the development of the JCE doctrine under international criminal law in the next sections. It is important to understand whether there is a mismatch of the level of culpability and the degree of liability for some or all of the international crimes and, if so, whether the ICTY judges should take a similar approach to the UK Supreme Court judges and overturn the JCE doctrine, which may have taken a wrong turn $^{48}$ in its development over the years of its existence.

\section{Assessing the Degree of Liability for the Commission of Crimes under JCE: Is It Similar to Actual Perpetration or to Aiding and Abetting?}

This section is dedicated to the assessment of the degree of liability for participation in JCE III. As discussed in the previous section, the degree of liability can be assessed by considering how the person's participation in crime makes them liable (what they are guilty of) and the seriousness of the punishment for that participation. Accordingly, what is considered in this section is how the law responds to particular conduct, rather than whether, and to what extent, the person's conduct is

\footnotetext{
${ }^{44}$ Popović Trial Judgement, paras. 1086-1087.

${ }^{45}$ See for example ibid., paras. 1090; 1337-1343, etc.

${ }^{46}$ Ibid., paras. 1299-1300; 1339; 1412, etc.

${ }^{47}$ See ibid, paras. 83-84.

${ }^{48}$ Ibid., para. 85.
} 
blameworthy (which is a matter of culpability, not liability). In order to provide an appropriate assessment of the degree of liability for participation in JCE III, it should be compared with the degree of liability for aiding/abetting. A similar comparison will be made in the next section for the purposes of assessing the level of culpability for participation in JCE III.

It is well known that JCE liability was not directly mentioned in the ICTY/ICTR statutes. Article 7(1) was interpreted by the ICTY Appeal Chamber in the Tadić case as to include, among other modes of liability, the liability under JCE. ${ }^{49}$ This mode of liability was considered to be a form of 'commission' for the purposes of Article 7(1) of the ICTY statute (corresponding Article 6(1) of the ICTR statute). ${ }^{50}$ By analogy, the same applies to the ICTR jurisprudence due to the fact that ICTY and ICTR statutes have 'mirror' articles identifying the modes of liability. ${ }^{51}$

Another form of commission, which exists in the Tribunals' jurisprudence, is actual or physical perpetration of the crime. ${ }^{52}$ If both of these forms of commission are embraced by the same word 'commission' under the ICTY/ICTR statutes, it can be presumed that the liability under both of them will be of the similar high degree ${ }^{53}$ and attract similarly serious consequences with regard to the punishment and sentencing.

From the punishment point of view, the Appeal Chamber stated that the distinction does not need to be made between a physical perpetrator of the crime and a member of JCE for the determination of the sentence. ${ }^{54}$ The sentence under the JCE mode of liability can be even higher than for physical perpetration. ${ }^{55}$ Due to the nature of the crimes that are committed, ${ }^{56}$ the ICTY Appeals Chamber clearly indicated that it is wrong to suggest that the responsibility and sentence of the defendant 'should be adjusted to account for the fact that he did not personally commit any of the crimes, for which he is held responsible pursuant to joint criminal enterprise. ${ }^{57}$ Nevertheless, here, the Chamber

\footnotetext{
${ }^{49}$ See Tadić Appeal Judgement, para. 220.

${ }^{50}$ Tolimir Appeal Judgement, para. 281; Popović et al. Appeal Judgement, para. 1672; Đorđević Appeal Judgement, paras. 56, 58; Prosecutor v. Krajišnik, Case No. IT-00-39-A, Judgement, 17 March 2009 ('Krajišnik Appeal Judgement'), paras. 662,665 .

51 Prosecutor v. Ntakirutimana and Ntakirutimana, Case Nos. ICTR-96-10-A and ICTR-96-17-A, Judgement, 13 December 2004, para. 468.

${ }^{5}$ See Đorđević Appeal Judgement, para. 56; Prosecutor v. Munyakazi, Case No. ICTR-97-36A-A, Judgement, 28 September 2011, para. 135; Tadić Appeal Judgement, para. 188, considering that covers first and foremost the physical perpetration of a crime.

${ }^{53}$ See also S. Manacorda, C. Meloni, 'Indirect perpetration versus joint criminal enterprise: concurring approaches in the practice of international criminal law?' 9 Journal of International Criminal Justice (2011) 159, p. 174; F.Z. Guistiniani, 'Stretching the boundaries of commission liability: the ICTR Appeal Judgemetn in Seromba', 6 Journal of International Criminal Justice (2008) 783, p. 799.

${ }^{54}$ Prosecutor v. Krnojelac, Case No. IT-97-25-A, Judgement, 17 September 2003, para. 75. This is despite the fact that the STL Appeals Chamber accepted that the culpability of secondary offender (member of JCE) is less than primary offender (physical perpetrator) and should be taken into account at the sentencing stage. See also van Sliedregt (2012), supra note 13 , p. 81.

${ }^{55}$ Krnojelac Appeal Judgement, para. 75.

${ }^{56}$ Krajišnik Appeal Judgement, paras. 663-665; Prosecutor v. Kvočka et al., Case No. IT-98-30/1-A, Judgement, 28 February 2005, ('Kvočka et al. Appeal Judgement'), para. 80; Đorđević Appeal Judgement, para. 57.

${ }^{57}$ Đorđević Appeal Judgement, para. 57.
} 
seems to conflate the seriousness of crimes committed and the degree of defendants' participation in them. While the former would affect the degree of harm to the society by one particular crime, the latter will affect the degree of the individual's culpability. The former focuses on the victim/society, the latter focuses on the defendant, and these are two different perspectives.

Although the degree of defendants' involvement in the crimes is considered by the Chambers in the discussion of aggravating factors, this involvement is discussed from the position of the responsibility for the 'commission' of the crime. That means that the starting point is the commission of the crime and already a high level of sentence, which may be aggravated further by a higher degree of participation of the defendant in the JCE. ${ }^{58}$ In addition, when discussing the sentence, the Chambers do not seem to make a distinction between JCE I and JCE III commission. Some authors, however, argue that a distinction should in fact be made in the sentencing for JCE I and JCE III liability to adequately reflect the culpability and participation of the person in a particular crime. ${ }^{59}$ Therefore, given that JCE III, as a form of commission, is considered the same as JCE I for punishment purposes and attaches the same label of perpetration as a physical perpetration of the crime, the degree of liability (from both labelling and punishment points of view) is very high and not less than for physical perpetration.

Comparing the commission by JCE III with aiding and abetting, the latter will attract lesser sentence than the participation in JCE. ${ }^{60}$ This is due to the fact that the acts of a JCE member are considered to be more serious than those of an aider and abettor, ${ }^{61}$ because aiding and abetting is regarded as involving a lesser degree of individual criminal responsibility than participation in a JCE. ${ }^{62}$ It was clearly recognised by the ICTY Appeals Chamber that aiding/abetting attracts a lesser degree of criminal liability than committing a crime, which includes participation in a JCE (including JCE III). ${ }^{63}$ Similarly, for the punishment purposes, the commission under JCE is equated to the physical

\footnotetext{
${ }^{58}$ See for instance Tolimir Appeal Judgement, para. 633, where the Appeals Chamber approved the approach of the Trial Chamber in considering the degree of involvement of the defendant in the JCE as an aggravating factor, rather than on the stage where the gravity of the offence/conduct is discussed.

${ }^{59}$ See van Sliedregt (2007), supra note 13, p. 205.

${ }^{60}$ See also van Sliedregt (2012), supra note 13, p. 71, stating that a de facto mitigating principle is developed at ICTY in relation to aiding/abetting. See also A. Cassese and others (2009), supra note 7, p. 300. That was also confirmed in the empirical research on sentencing. See B. Holá, A. Smeulers, C. Bijleveld, 'Sentencing Practice at the ICTY and ICTR,' 9 Journal of International Criminal Justice (2011) 411, p. 429; B. Holá, A. Smeulers, C. Bijleveld, 'Is ICTY Sentencing Predictable? An Empirical Analysis of ICTY Sentencing Practice,' 22 Leiden Journal of International Law (2009) 79, p. 91. However, it was shown in the latter article (p. 92) that unlike on Trial (where the sentencing for aiding/abetting is lower than sentencing for JCE), the sentencing on Appeal was changed, so that the average sentence for aiding/abetting became higher than for JCE. The authors explained that by the existence of additional relevant sentencing factors, which lower sentences for JCE participants or increase sentences for aiders/abetters, including the fact that on Appeal the original convictions under JCE mode of liability were downgraded to aiding/abetting, but the judges did not want to significantly alter the original sentence pronounced for JCE participants at trial (p. 92).

${ }^{61}$ Krnojelac Appeal Judgement, para. 75.

${ }^{62}$ Kvočka et al. Appeal Judgement, para. 92. See also STL Decision, para. 249. See also F.L. Guistiniani, 'The responsibility of accomplices in the case-law of the ad hoc tribunals', 20 Criminal Law Forum (2009) 417, p. 440.

${ }^{63}$ See Prosecutor v. Vasiljević, Case No.: IT-98-32-A, Judgement, ('Vasiljević Appeal Judgement'), 25 February 2004, para. 102. See also Ambos, supra note 11, p. 171.
} 
perpetration, but the conduct amounting to aiding and abetting attracts lesser punishment. Therefore, the degree of liability from both labelling and punishment points of view is lower for aiding/abetting and higher for JCE III as a form of commission.

Even if the Tribunals had treated the liability under JCE and the physical perpetration differently for the imposition of the sentence, that would not change the overall trend and the presumption that the liability for both of them is of similar degree and it is higher than the liability for aiding/abetting. Labelling the JCE liability as 'commission' also creates a stigma on the defendant of having actually committed an international crime and not simply assisted in its commission. ${ }^{64}$ That also indicates a very high degree of liability for participation in JCE III.

The next section will consider whether the level of culpability does match the high degree of liability under JCE III through the analysis of the threshold of actus reus/mens rea required to find a person liable under JCE III.

\section{Assessing the Level of Culpability under JCE III through the Threshold of Actus Reus/Mens Rea: Does the Level of Culpability Match the Degree of Liability?}

Having assessed the degree of liability under the JCE doctrine, which appears to be very high, further analysis is needed of the assessment of the level of culpability that the person should have to be convicted of a crime under JCE mode of liability. This assessment will aim to respond to the question of whether the high degree of liability under JCE will have a corresponding high level of culpability of the person's actions. This analysis will be carried out with a particular emphasis on JCE III, which is a more controversial mode of liability than its counterparts (JCE I and JCE II).

In order to achieve this aim, it is necessary to consider actus reus and mens rea for JCE III. They will help to identify the degree of liability and the level of culpability in their relationship and link both liability and culpability together. Taking into account that if the culpability of the conduct of the person passes a certain threshold of mens realactus reus, the person becomes liable (reaches the certain degree of liability), the threshold of mens realactus reus required to be fulfilled by JCE determines both the degree of liability and the level of culpability.

These concepts are dependent on each other. If the threshold of mens realactus reus is high, then there should be more culpable conduct to satisfy this high threshold. At the same time, the level of mens rea and actus reus would determine a person's liability, i.e. whether the defendant is guilty or not guilty, and which punishment or sentence will be imposed. If the threshold of mens rea and actus reus is high (e.g. specific intent and physical perpetration of the crime), the liability of the person

\footnotetext{
${ }^{64}$ See also STL Decision, para. 249 on the same point.
} 
should be high as well (determination of guilt for commission and the attached high level of punishment). In this case, the higher degree of liability will match with the higher level of culpability. However, there may be situations where a higher degree of liability may have a lower threshold of mens rea and actus reus to be satisfied (e.g. a very low level of involvement of a person in a crime with low mens rea leading to finding of guilt and a high level of punishment). A lower threshold of mens realactus reus would lead to a lower level of culpability and therefore the higher degree of liability would not match the level of culpability.

Thus, in order to find out whether under JCE III the liability and culpability coincide, we need to look at the threshold of mens realactus reus required under JCE III. As was concluded above, there is a very high degree of liability that is attached to the commission of crimes under JCE (including JCE III). It is of equal level to the physical perpetration of the crimes. Accordingly, the threshold of mens realactus reus required under JCE should also be very high, ideally comparable to the physical perpetration of the crime. Failing that, the level of culpability would be too low for such a high degree of liability. That would mean that individuals with a low level contribution may be 'equally guilty' to those who physically committed the same crime. ${ }^{65}$ The further analysis will consider the threshold of actus reus/mens rea required for a person to be convicted under JCE (with particular emphasis on JCE III).

\subsection{Dissecting JCE III Doctrine: What is the Defendant Liable for?}

The elements of JCE III are well established. The actus reus for JCE III is the plurality of persons involved; the common criminal purpose amounting to the commission of a crime; and the defendant's participation in the common purpose by making significant contribution to furthering criminal purpose. ${ }^{66}$ The mens rea is the intent to further criminal purpose, the foreseeability of the risk that the additional crime might be committed and that the defendant willingly took that risk. ${ }^{67}$

In order to analyse and compare the threshold of actus reus/mens rea of JCE III, it is necessary to dissect the JCE III doctrine in a way, which allows us to look separately at the degree of involvement of the defendant in each of the crimes the JCE III embraces. The nature of the JCE III doctrine presupposes the defendant's involvement in at least two crimes: the first crime is the crime, which constitutes the purpose of the JCE III ('the common purpose crime'), and the second crime is the foreseeable crime, or extended crime, which was actually committed.

The second step is to separate the mens realactus reus requirements for each of the crimes forming part of the JCE III. In fact, the actus reus requirements of the existence of common criminal purpose

\footnotetext{
${ }^{65}$ See Robinson, supra note 11, p. 940.

${ }^{66}$ Kvočka et al. Appeal Judgement, para. 96; Tadić Appeal Judgement, para. 227.

${ }^{67}$ See inter alia Popović Appeal Judgement, para. 1431; Prosecutor v. Brđanin, Case No. IT-99-36-A, Judgement, 3 April 2007, ('Brđanin Appeal Judgement’), paras. 365, 411; Tadić Appeal Judgement, para. 227.
} 
and a significant contribution refer to the first crime, not to the second crime. The intent to commit a crime (to further a criminal purpose) is also related to the commission of the first crime, not to the second crime. At the same time, there is no requirement that the first crime must actually be committed. ${ }^{68}$

There must be proof that a second crime has been committed. However, the involvement of the defendant in its commission is somewhat limited. While they should make a significant contribution to furthering the commission of the first crime, this does not necessarily mean that the same applies to the second, foreseeable crime, that was actually committed. ${ }^{69}$ At the same time, the mens rea for the second crime is reduced to dolus eventualis or advertent recklessness. ${ }^{70}$ It should be reiterated that, although there is a requirement of intent present in JCE III, it is related to the first crime, not to the second crime.

This analysis is important for establishing the level of culpability, because the defendant will be charged and (if proven) found guilty for each crime separately. It is especially so, because under JCE III they are charged with the second crime, not the first crime. The first crime may appear in the indictment in a separate count (as a JCE I) and the person will be considered liable for that crime separately. ${ }^{71}$ Therefore, the level of culpability in question should be analysed in relation to the second crime, not the first crime, because JCE III liability charges concern the foreseeable crime (i.e. second crime), not the ones that were originally intended under the common purpose (i.e. first crime).

Thus, the level of culpability of the person under JCE III will be shown by the mens realactus reus of the second crime, which is the foreseeability of the risk that the second crime might be committed as a result of the existence of a criminal purpose and the defendant's contribution to it.

The further analysis aims to reveal whether the mens realactus reus threshold for the second crime is high enough for the level of culpability to correspond to the degree of liability for the second crime. In order to do that, the discussion will involve the comparison of actus reus and mens rea

\footnotetext{
${ }^{68}$ The ICTY case-law, primarily the Brđanin case, seem to suggest that. It was held that a 'different' crime can in fact be committed instead of the common purpose crime and the defendant would be responsible for it if it was foreseeable (see Brđanin JCE III Appeal Decision, para. 6). In its full Judgement, the Appeals Chambers also held that if a JCE member uses a non-member, who in addition to or 'instead of' committing the crime forming part of the common purpose commits foreseeable crimes, all JCE members will be responsible for it (see Brđanin Appeal Judgement, para. 411). The use of 'instead of' here would mean that non-members or members of JCE do not need in fact to commit the main JCE crime, as long as other foreseeable crimes are committed.

${ }^{69}$ See discussion below in relation to the contribution to the JCE purpose, not to the foreseeable crimes.

${ }^{70}$ Brđanin Appeal Judgement, paras. 365, 411; Tadić Appeal Judgement, para. 220.

${ }^{71}$ If a person is not convicted in JCE I (i.e. was not participating in the common purpose with sufficient intent), they cannot satisfy the common purpose element of JCE III and would not be convicted under JCE III (see e.g. Popović Trial Judgement, paras. 1395, 1495, 1541, 1979, 2007). Hence, in order for a person to be convicted in JCE III, the person should be convicted in JCE I for the same purpose crime, which was confirmed by Popović Trial Judgement, para. 2013. Therefore, the liability of the defendant for the common purpose crime would be originally determined under JCE I and then the liability for extended crimes will be considered under JCE III. In this way, the liability for the common purpose crime is separate from the liability for the extend crime(s). See examples in Popović Trial Judgement, paras. 1073, 10801082, 1087-1088; 1168-1169; 1392-1393; 1717-1718, 1727, 1735; Prosecutor v. Tolimir, Case No. IT-05-88/2-T, Judgement, 12 December 2012 ('Tolimir Trial Judgement'), paras. 1185, 1195.
} 
requirements for the JCE III with the requirements for aiding/abetting (the liability for which is lower than for JCE III). If the mens rea and actus reus threshold for JCE III is higher than for aiding/abetting, then the level of culpability will roughly match the degree of liability. If the threshold of mens rea and actus reus for JCE III is lower, than for the aiding/abetting, the lower level of culpability will attract a much higher degree of liability, ergo, there will be a mismatch of culpability and liability for the defendants convicted under JCE III, which would confirm the main contention of this article.

\subsection{Comparing Actus Reus of JCE III and Aiding and Abetting: Which one Entails a Higher Level of Culpability?}

Before comparing the actus reus/mens rea for JCE III with the same for aiding/abetting, it is necessary to briefly outline the elements of aiding/abetting. The actus reus of aiding/abetting consists of assisting, encouraging or lending moral support to the commission of a crime and, by that, providing a substantial contribution to the perpetration of the crime. ${ }^{72}$ The mens rea of aiding/abetting is the knowledge of the defendant that their acts or omissions assist in the commission of the crime and that one of a number of crimes (not necessarily the precise crime) will probably be committed or is in fact committed. $^{73}$

One requirement caused a particular controversy in recent decisions of the ICTY. This was the requirement that the actions of the defendant to be 'specifically directed' to assist, encourage or lend moral support to the perpetration of the crime. While the Appeals Chamber in the Perišić case held that there is such a requirement, ${ }^{74}$ the Appeals Chamber in the Šainović et al. case, after extensive analysis of the customary international law, explicitly departed from the Perišić judgment and held that there is no such a requirement. ${ }^{75}$ Therefore, this requirement will not be considered for the present purposes.

\footnotetext{
72 Popović Appeal Judgement, para. 1732; Prosecutor v. Šainović et al., Case No. IT-05-87-A, Judgement, 23 January 2014, ('Šainović et al. Appeal Judgement'), paras. 1649, 1772; Prosecutor v. Blaškić, Case No.: IT-95-14-A, Judgement, 29 July 2004, ('Blaškić Appeal Judgement'), paras. 46, 50. Prosecutor v. Stanišić and Simatović, Case No. IT-03-69-T, Judgement, 30 May 2013, ('Stanišić and Simatović Trial Judgement'), para. 1264.

73 Popović Appeal Judgement, para. 1732; Šainović et al. Appeal Judgement, paras. 1649, 1772; Blaškić Appeal Judgement, paras. 46, 50; Stanišić and Simatović Trial Judgement, para. 1264.

${ }^{74}$ Prosecutor v. Perišić, Case No. IT-04-81-A, Judgement, 28 February 2013, ('Perišić Appeal Judgement'), para. 36.

75 Śainović et al. Appeal Judgement, para. 1649. See Šainović et al. Appeal Judgement, paras 1626-1648, 1650. See also Popović Appeal Judgement, para. 1758, affirming this judgement. For academic discussion on this point, see D. Steward, 'Can the ICTY Šainović and Perišić cases be reconciled,' 108 American Journal of International Law (2014) 475; A. Coco, T. Gal, 'Losing Direction: the ICTY Appeals Chamber's Controversial Approach to Aiding and Abetting in Perišić,' 12 Journal of International Criminal Justice (2014) 345; M. Aksenova, 'The specific direction requirement for aiding and abetting: a call for revisiting comparative criminal law,' 4 Cambridge Journal of International and Comparative Law (2015) 88; M. Ventura, 'The War Report: Armed Conflict in 2013: Chapter 13 Farewell 'Specific Direction': Aiding and Abetting War Crimes and Crimes against Humanity in Perišić, Taylor, Šainović et al., and US Alien Tort Statute Jurisprudence,' Geneva Academy of International Humanitarian Law and Human Rights (2013).
} 


\subsubsection{Significant v. Substantial Contribution}

It should be firstly explored whether the defendant's contribution to the commission of the second crime of JCE III is higher than the contribution to the crime in aiding/abetting. It was repeatedly held by the ICTY Chambers that, in order to be charged with aiding/abetting, the contribution of the defendant to the crime should be substantial. ${ }^{76}$ At the same time, it was also held that to be liable under JCE, the defendant does not need to make a substantial contribution i.e. a significant contribution will be enough. ${ }^{77}$ In this way, the threshold of contribution defined by the ICTY jurisprudence is lower for the JCE III than for aiding/abetting. ${ }^{78}$

An additional question is whether the defendant must significantly contribute to the furthering of criminal purpose (i.e. for the first crime) or to the foreseen crime (the second crime). The ICTY jurisprudence does not seem to be very settled on this point. Some Chambers considered that the contribution should be for the common purpose or crimes envisaged by the common purpose or JCE. ${ }^{79}$ The others stated that the contribution of the defendant should be significant to the 'crimes for which the accused was found responsible. ${ }^{80}$ The latter wording might mean that the significance of the contribution should be assessed for each of the crimes the defendant is charged with, including the second crime under JCE III.

Against this background, there is a consistency of interpretation of the Chambers of 'significant contribution' in relation to the crimes forming part of the criminal purpose. The Krajišnik Appeals Chamber itself held that the accused needed to lend 'a significant contribution to the commission of the crimes involved in the JCE' and 'beyond that, the law does not foresee specific types of conduct which per se could not be considered a contribution to the common purpose. ${ }^{91}$

In fact, in relation to the actus reus for JCE III, the significance of the contribution is normally assessed, when the Chambers consider the defendant's participation in JCE, not when they consider

\footnotetext{
${ }^{76}$ Popović Appeal Judgement, para. 1732; Prosecutor v. Gotovina and Markač, Case No. IT-06-90-A, Judgement, 16 November 2012, ('Gotovina Appeal Judgement'), para. 143.

${ }^{77}$ Krajišnik Appeal Judgement, para. 215; Brđanin Appeal Judgement, para. 430.

78 See Gotovina Appeal Judgement, para. 143; see also Kvočka et al. Appeal Judgement, para. 97; Tadić Appeal Judgement, para. 229.

${ }^{79}$ The Appeals Chamber held that the accused must 'perform acts that in some way are directed to the furthering of the JCE in the sense that he significantly contributes to the commission of the crimes involved in the JCE.' (see Krajišnik Appeal Judgement, para. 695, see also Kvočka et al. Appeal Judgement, paras. 97, 104). It is also often held that 'the participation of an accused person in a JCE need not involve the commission of a crime, but that it may take the form of assistance in, or contribution to, the execution of the common objective or purpose.' (see Krajišnik Appeal Judgement, para. 215; Kvočka et al. Appeal Judgement, para. 97; Ntakirutimana Appeal Judgement, para. 466; Krnojelac Appeal Judgement, paras 31 and 81; Tadić Appeal Judgement, para. 227(iii)).

80 Stanišić and Simatović Trial Judgement, para. 1258; Brđanin Appeal Judgement, para. 430; Krajišnik Appeal Judgement, paras. 215, 662, 675.

${ }^{81}$ Krajišnik Appeal Judgement, para. 696.
} 
the defendant's involvement in additional foreseeable crimes. ${ }^{82}$ The latter is a second stage of analysis, which does not include a separate consideration of the defendant's contribution. Additionally, there is no mention of an additional requirement that there should be significant contribution to the foreseeable crime as well. Therefore, it is unlikely that a significant contribution to the foreseeable crime will be required.

This issue clearly requires further clarification by the Tribunals because the culpability of a person for the foreseen crime may be much lower, if the contribution is assessed only in relation to the common purpose. Indeed, the contribution may be made only to the common purpose and not to the foreseen crimes.

The following situation may happen. The defendant is charged with murder under JCE III. The common purpose was to forcibly remove a group of people from a territory controlled by the army. In execution of the common purpose, some people were killed. The defendant contributed to the criminal purpose (to remove a group of people) providing a vehicle for them to be removed. This would be a significant contribution, as otherwise, the perpetrators would not be able to remove people. However, these actions would not contribute to the killings of individuals, as they are not connected, and if the vehicle was not provided, the people could still be killed. The question is whether this type of contribution would be enough to convict the defendant of murder under JCE III. If the previously explained logic is correct, then the defendant's contribution would be considered only to the furthering of criminal purpose (and not in relation to the murder), the culpability of the defendant for the crime of murder (the charge under JCE III) will be much lower. ${ }^{83}$

It can be argued that the culpability of persons under JCE is higher than for aiding/abetting because they are involved in a common criminal purpose and the fact of their involvement would attract a higher level of culpability. This argument is largely based on the public policy rationale of greater punishment for a group or collective crime, which is perceived to be able to cause more harm. ${ }^{84}$ However, this argument can be disputed.

Firstly, this argument seems to suggest that the actus reus of the involvement in the group crime would compensate for a low mens rea requirement (foresight), which goes against the criminal law

\footnotetext{
${ }^{82}$ Although the foreseeable crime is an extension of the first, common purpose crime, as discussed above, two crimes should be assessed separately due to the fact that a separate conviction would be entered in relation to the defendant's involvement in the first crime. At the same time, the reduced mens rea (foresight) for the extended crime should not affect the actus reus (significant contribution) requirement. The present analysis for the purposes of culpability focuses on the level of actus reus and mens rea required separately for the second crime to be convicted in under JCE III.

${ }^{83}$ Although there could be proof of foresight of the murder (mens rea), which is already lower than the one required to convict a physical perpetrator in murder, the problem is that actus reus is for the extended crime is only linked to the common purpose crime (a significant contribution and participation in the common plan), for which the person would be separately charged under JCE I.

${ }^{84}$ See STL Decision, para. 245; J. Doria, 'The relationship between complicity modes of liability and specific intent crimes in the law and practice of the ICTY', in J. Doria, H. Gasser, M. C. Bassiouni (eds.), The legal regime of the International Criminal Court: essays in honour of Professor Igor Blishchenko (Martinus Nijhoff Publishers, Leiden, 2009); Cassese (2007), supra note 7, pp. 110, 117-118; Cassese and others (2009), supra note 7, pp. 328-329.
} 
logic of separate assessment of mens rea and actus reus requirements. Moreover, as discussed above, the fact that the defendant had a full intent to participate in the criminal purpose crime (mens rea of JCE) is already taken into account when assessing the defendant's responsibility for JCE I, before the responsibility for JCE III is considered.

Secondly, another problem with this 'collective crime' policy argument is that it seems to conflate the impact on society of the collective participation in a crime with the individual involvement of particular person in that crime. In this sense, the 'collective' nature of the crime committed is akin to the gravity or seriousness of the crime, the individual involvement of the crime is a completely separate issue. A person cannot be found guilty of a crime, if they had a very vague (next to nothing) involvement in it, even if it was the most serious crime in the world. The seriousness of the crime itself does not make them guilty of it. Whilst a participation in the 'collective crime' should be condemned, only those who were involved in the crime (with sufficient mens rea), should be punished for it.

Thirdly, on a more technical point, looking purely at the actus reus requirements of JCE III and aiding/abetting, in addition to the 'significant contribution,' other elements of the actus reus of JCE III are the plurality of persons involved and the existence of common criminal purpose. The first element - the plurality of persons involved - is the element for both JCE and indirectly for aiding/abetting. It is because, in aiding/abetting, there will also be plurality of persons involved - the physical perpetrator and the person who aids/abets. With regard to the second element - the existence of common criminal purpose, it does not change anything either. This arises from the fact that, both in JCE and aiding/abetting, people get involved in the same illegal conduct, whether or not there is an identified criminal purpose among them.

Moreover, the existence of both elements is an objective factor, not linked to the defendant. It is the defendant's involvement in common criminal purpose or aiding/abetting, which makes their conduct criminal. It is the degree of the defendant's involvement (reflected by the substantial/significant contribution discussed above), which defines whether their conduct is criminal or not and reflects their culpability in that crime. Accordingly, given that the level of contribution required for aiding/abetting (substantial contribution) is higher than for JCE (significant contribution), and other parts of actus reus are similar and/or independent from the defendant's acts, the threshold of actus reus for JCE is lower than for aiding/abetting. Thus, it is the higher threshold of mens rea requirement, which should reflect the high degree of liability under JCE III, as actus reus does not do that. ${ }^{85}$

\subsubsection{Non-Members Committing Crimes}

\footnotetext{
85 This issue will be analysed in the next section.
} 
The aforementioned point is particularly true, when we look at the extension of JCE III liability for the foreseen crimes of non-members of the JCE. It was held in the Brđanin case that if the defendant or any other member of JCE uses other people for the commission of the crimes to further common purpose (even if they are not members of JCE and even unaware of it), ${ }^{86}$ the defendant may be liable for those crimes. ${ }^{87}$ This is so, even if those non-members commit foreseeable crimes not forming part of criminal purpose. ${ }^{88}$ In order to establish the liability of JCE members for non-members' acts, it should be shown that the crime can be imputed to one JCE member, who acted in accordance with the common plan when using a physical perpetrator. ${ }^{89}$

This inclusion of responsibility for the crimes of non-members broadened even further the liability under JCE III and reduced the level of culpability required. As the common criminal purpose can be a legitimate purpose (establish control over a territory) to be achieved by unlawful means, it is possible to envisage a situation when a commander of a military unit may be liable for the crimes committed by soldiers in another military unit due to him choosing to obey the order of a commander of a higher rank, which required the use of all necessary means, including pillage to achieve certain military aim (e.g. establish control over a territory). All necessary means and a possibility of pillage indicate a common criminal purpose. The order itself would be the evidence of common criminal purpose. If a commander executes the order (even without actually committing the crime), being aware that the crime of pillage is envisaged, he may be found to participate in the JCE together with other unit commanders. That is because being aware of the order, he did not resign (withdraw from JCE) and contributed to its execution (e.g. ordered his subordinates to comply with it).

If his subordinates commit pillage, the commander will be responsible for it under JCE I. It may be accepted by the Chamber that crimes of murder would be a natural and foreseeable consequence of the order, given that it allowed to use all necessarily means including pillage. Moreover, being involved in pillage, the soldiers understandably being armed, may kill somebody. The commander of the unit will be then responsible for murder under JCE III, even if the soldiers were not considered as members of the JCE. However, this is not the end of the story. If the first commander's soldiers do not do anything wrong, but the soldiers of another unit (commanded by another commander) commit crimes (including murders), the first commander may still be responsible for them under JCE III, ${ }^{90}$

\footnotetext{
${ }^{86}$ See Brđanin Appeal Judgement, para. 410, where it was held that the knowledge of a non-member about JCE is not a sine qua non condition to establish the liability of the defendant.

${ }^{87}$ Brđanin Appeal Judgement, paras. 410-411; See also Popović Appeal Judgement, para. 1414; Đorđević Appeal Judgement, para. 63.

${ }^{88}$ Brđanin Appeal Judgement, para. 411.

${ }^{89}$ Ibid., para. 413.

${ }^{90}$ See also C. Farhang, 'Point of no return: joint criminal enterprise in Brđanin', 23 Leiden Journal of International Law (2010) 137, pp. 154-155.
} 
because a person can be responsible for the foreseeable crimes of non-members who are linked to another member of the JCE (in this case, another commander). ${ }^{91}$

This situation shows how the current state of law on JCE III can extend the liability of those who do not take major decisions but may still be found liable for very serious crimes that they have a very tenuous link to.

Some authors argue that a causal link between the defendant in JCE III and the perpetrated crime by another person will be established due to the fact that defendant's participation in, and failure to withdraw from, the common plan rendered possible the perpetration of second, foreseeable crime. ${ }^{92}$ This, however, may not be the case for the crimes committed by non-members of JCE. A tenuous link between the defendant and the foreseeable crime perpetrated by a non-member may lead to the situation where the crime committed by a non-member employed by a JCE member would be too remote from the actions or contribution of the defendant. This is especially so because there is no formal requirement that the defendant being aware that another member would use non-members to commit crimes forming part of the common purpose. ${ }^{93}$ The defendant does not need to be aware of the identity of non-members and of the crimes they commit, as long as they were foreseeable for him or her at that point of time.

The only link between the defendant and the physical perpetrators is another JCE member, who uses non-members to commit crimes. That JCE member may be acting completely autonomously in their decision to use non-members to further criminal purpose. Their autonomous actions may break a chain of causation between the defendant and non-members whom he may not even know about and whose crimes become too remote. The foreseeability requirement does not save the situation, as although the crimes may be foreseen, the identity of perpetrators may not. This situation therefore may break the causation element of commission of the crime. This would mean an even lower level of culpability to be sufficient for a very high degree of liability for the crime.

\subsection{Comparing Mens Rea of JCE and Aiding/Abetting: Which One Entails Higher Culpability?}

The mens rea requirements that will be compared are the following. For JCE III, the mens rea consists of the intent to participate in JCE (intent for the first crime) and the foresight that the second crime might be committed (advertent recklessness or dolus eventualis). ${ }^{94}$ The mens rea for aiding/abetting

\footnotetext{
${ }^{91}$ See Prosecutor v. Radovan Karadžić, Case No. IT-95-5/18-AR98BIS.1, Judgement, 11 July 2013 ('Karadžić Rule 98bis Judgement'), para. 79, Krajišnik Appeal Judgement, para. 225. See also Brđanin Appeal Judgement, para. 410.

${ }_{92}$ See Cassese and others (2009), supra note 7, p. 326.

${ }^{93}$ See C. Farhang, supra note 90, p. 150.

${ }^{94}$ Brđanin Appeal Judgement, paras. 365, 411; Tadić Appeal Judgement, para. 220.
} 
is the knowledge that the acts of the defendant assist in the commission of the crime and the awareness that the crime (or some type of the crime) will probably be committed. ${ }^{95}$

As was mentioned before, for the purposes of the defendant's culpability, the mens rea and actus reus requirements should only be taken into account for the second, extended crime, not for the first, common purpose crime. The reason is because the person would already be charged and found participating in the common purpose crime as part of JCE I (or JCE II), if the liability for the extended crimes under JCE III is to be considered. ${ }^{96}$ Therefore, the mens rea for only the second crime could determine the culpability of the defendant for that particular crime, unless the first crime forms part of the second crime.

An example of that would be if the criminal purpose was to commit inhuman treatment but, in fact, torture was committed. The mens rea for the first crime could be taken into account for the second crime in assessing culpability, because the former forms part of the latter.

However, if the criminal purpose was to commit pillage, and in fact a rape or murder were committed, the mens rea for those crimes is substantially different. In this case, a person may be charged with pillage under JCE I and murder under JCE III under a separate count. The culpability must be assessed for each of them individually. Therefore, the original mens rea of pillage, or intent to further criminal purpose, cannot be taken into account, when assessing the culpability of the defendant for murder under JCE III. As explained above, what is to be considered is the mens rea for the second crime only under JCE III for culpability purposes.

In this way, the mens rea for a second crime would be the foreseeability that the crime might be committed and that the defendant willingly took that risk (dolus eventualis or advertent recklessness). ${ }^{97}$ This is compared with the mens rea for aiding/abetting being the awareness that the crime will be committed and the awareness that the actions assist in the commission of the crime.

The mens rea for a second, extended crime of JCE III (not taking into account the mens rea for the first, common purpose crime, which is already assessed for the purposes of JCE I (or JCE II) liability) seems to be lower than the mens rea for aiding/abetting. The reasons for this are, firstly, aiding/abetting requires awareness or knowledge, whereas JCE III only requires foreseeability (even enhanced with willingness to take a risk), which is lower than the knowledge requirement, ${ }^{98}$ which

\footnotetext{
95 Popović Appeal Judgement, para. 1732; Šainović et al. Appeal Judgement, paras. 1649, 1772; Blaškić Appeal Judgement, paras. 46, 50 .

${ }^{96}$ See Popović Trial Judgement, para. 2013. See also Olasolo, supra note 11, p. 279.

${ }^{97}$ See inter alia Popović Appeal Judgement, para. 1431. Obviously, the ICTY jurisprudence has not taken into account the approach adopted in the Jogee case, namely that the foresight is mere evidence of intent. Instead, it merely required advertent recklessness or dolus eventualis to be established for the commission of any crime (including murder or genocide).

${ }_{98}$ See also H.G. van der Wilt, 'Genocide, complicity in genocide and international v. domestic jurisdiction', 4 Journal of International Criminal Justice (2006) 239, p. 247, also distinguishing positive knowledge and dolus eventualis, as being lower than positive knowledge requirement. See also Ambos, supra note 11, pp. 174-175, stating that knowledge is a standard for intent crimes, whilst foreseeability belongs to the theories of recklessness or negligence.
} 
shows more certainty in the outcome than a mere risk. Secondly, confirming the previous point, for aiding/abetting, the awareness that the crime 'will probably' be committed, whereas for JCE III, the crime 'might' or 'possibly' be committed, which is lower than a 'probability' standard. ${ }^{99}$ Thirdly, for aiding/abetting, the mens rea includes the awareness that the defendant's actions will assist the commission of the crime. For JCE III there is no such a requirement. The defendant's actions would be aimed to contribute to the first crime, but not necessarily for the second and this element is subsumed by the 'foreseeability of the crime', which is again lower than knowledge.

Thus, the comparison of elements of mens rea for the second crime of JCE III and aiding/abetting shows that the mens rea threshold for JCE III is lower than for aiding/abetting. That means that it would reduce the level of culpability for JCE III crime as well.

\subsection{JCE III and Specific Intent Crimes: is JCE Doctrine already Overstretched?}

The next issue to be explored is the application of the JCE III in the cases of specific intent crimes (e.g. genocide, persecution, etc.), and whether the main contention of this article that the culpability is lower than liability under JCE III is particularly true for specific intent crimes.

The issue of application of JCE III for specific intent crimes, in particular genocide, proved to be one of the most controversial in international criminal law generally and in the JCE doctrine in particular. ${ }^{100}$ This is due to the fact that these crimes have an exceptionally high threshold of mens rea to be fulfilled. A proof of specific intent (sometimes called dolus specialis, or ulterior intent) is required. ${ }^{101}$ In the hierarchy of levels of subjective elements (dolus eventualis (advertent recklessness) - dolus directus (intent) - dolus specialis (ulterior intent) - it is the highest.

The problem with JCE III is that the mens rea requirement for it is on the level of dolus eventualis (advertent recklessness), which is much lower than the mens rea requirement for specific intent crimes. ${ }^{102}$ Whereas JCE I requires to prove the full intent (be it dolus directus or dolus specialis), JCE III liability would be established, if only dolus eventualis (advertent recklessness) is proved. Despite that fact, the ICTY Appeals Chamber rejected this challenge stating that JCE III applies to all crimes,

\footnotetext{
${ }^{99}$ See Popović Appeal Judgement, para. 1432, distinguishing between 'would probably be committed' and 'might be committed'; see also Karadžić Appeal Decision, para 18, where the Chamber clearly stated that for JCE a lower standard is applicable - 'possible', not 'probable' (Prosecutor v. Karadžić, Case No. IT-95-5/18-AR72.4, Decision on Prosecution's motion appealing Trial Chamber's decision on JCE III foreseeability, 25 June 2009).

100 See Beara's Appeal Brief in the case Popović et al., para. 292-302 and Miletić Appeals brief, paras. 376-378, see also Popović Appeal Judgement, paras. 1437, 1440, 1707-1708; Đorđević Appeal Judgement, para. 73-81; see also Bantekas, supra note 13, p. 57; van Sliedregt, supra note 13, p. 190.

${ }^{101}$ See Tolimir Appeal Judgement, paras. 246-257; Prosecutor v. Krstić, Case No: IT-98-33-A, Judgement, 19 April 2004, ('Krstić Appeal Judgement'), para. 20; see also Olasolo, supra note 11, p. 284.

102 See also R. Provost, P. Akhavan, F. Megret, M. Duffy, C.I. Fuentes, A. Khoday, M. M. Casagrande, M. Dort, J. Hirsch-Allen, S. Tremblay, S. Jodoin, 'Amicus curiae brief on joint criminal enterprise in the matter of the Co-Prosecutors' appeal of the closing order against Kaing Guek Eav 'DUCH', 20 Criminal Law Forum (2009) 331, p. 348; Bantekas, supra note 13, p. 57; van Sliedregt (2007), supra note 13, p. 191.
} 
including specific intent crimes. ${ }^{103}$ Such a reduction of mens rea requirement may mean an even lower level of culpability for specific intent crimes. ${ }^{104}$ Therefore, this section will consider whether culpability and liability for specific intent crimes under JCE III mismatch to even a greater extent than for other crimes.

\subsubsection{Do JCE III and Specific Intent Crimes Conceptually and Logically Match?}

As discussed above, due to the fact that a person is charged with the second crime (foreseeable) under JCE III not the first crime (the purpose crime), the culpability is assessed in relation to the second crime, in this case a specific intent crime. Given that the threshold of mens rea for JCE III is dolus eventualis (recklessness) and for specific intent crimes is dolus specialis (ulterior intent), the JCE III mode of liability reduces the required mens rea from dolus specialis to dolus eventualis and makes it easier to convict a member of JCE of the specific intent crime, rather than a physical perpetrator. ${ }^{105}$ The question is whether that is conceptually and logically correct.

An argument was put forward by the Chambers that given that the JCE III is a mode of liability and not a crime, ${ }^{106}$ it could have its own threshold. This argument seems to be misleading. It does not take into account that the JCE III liability is a liability for commission, together with a physical perpetration. The actus reus for JCE liability does not need to resemble physical perpetration, and, namely, does not need to include perpetration of actus reus of the crime. ${ }^{107}$ It is because it is a group liability, so that someone within the group may do that, as long as they have the same intent/purpose and they act together to further that criminal purpose. ${ }^{108}$ That is why the group as a whole 'commits' the crime. ${ }^{109}$

The JCE III should be the same concept. The group as a whole 'commits' the second crime, when one of them performs the actus reus and the rest act in concert with the same intent. The problem, which is exemplified by the specific intent crimes, is that not all members of the group will now be sharing the same intent, because although some of them have a specific intent for the crime, the others will be just foreseeing the crime and not sharing the specific intent. ${ }^{110}$

An argument may follow that that is the case for other crimes as well, and not only for specific intent crimes. This is not necessarily the case. Some crimes have dolus eventualis or advertent recklessness

\footnotetext{
${ }^{103}$ Popović Appeal Judgement, para. 1440; Đorđević Appeal Judgement, paras. 81, 84, 919-920; Brđanin JCE III Appeal Decision, para. 9.

${ }^{104}$ See also Cassese (2007), supra note 7, p. 121.

105 See Provost and others, supra note 102, p. 348.

${ }^{106}$ Kvočka Appeal Judgement, para. 91; Brđanin Appeal Decision, para. 5.

107 Brđanin Appeal Judgement, para. 427; Kvočka et al. Appeal Judgement, para. 99; Tadić Appeal Judgement, paras. 196, 227.

${ }^{108}$ See also Kvočka Appeal Judgement, para. 90.

${ }^{109}$ See also J.D. Ohlin, 'Second-order linking principles: combining vertical and horizontal modes of liability', 25 Leiden Journal of International Law (2012) 771, p. 787 discussing group liability.

110 See also Powles, supra note 10, p. 611.
} 
as the minimum mens rea requirement. This means that JCE III mens rea threshold matches the crime mens rea threshold and that does not generate a conceptual problem for treating JCE III as a form of commission (as at least mens rea for the crime is fulfilled).

It is not, however, the case for murder, where dolus directus or full intent is required. Although that is true, there are two possibilities to fulfil the intent for murder either proving the intent to kill or the intent to cause serious bodily harm, which the perpetrator should reasonably have known might lead to death. ${ }^{111}$ Therefore, in cases where it was intended by the defendant that some serious bodily harm would be caused to victims (whatever the criminal purpose was), in the event of murder being committed, as a foreseeable crime, the mens rea for murder will still be satisfied.

That may not be true when neither of the ways to establish the mens rea for murder is satisfied. These cases would have the same issue as the cases of specific intent crimes charged under JCE III, ${ }^{112}$ as the mens rea under JCE III will be reduced from dolus directus for murder and dolus specialis for specific intent crimes (genocide, persecution). If JCE III liability for specific intent crimes is criticised as reducing culpability required for conviction, then the JCE III liability for murder should be criticised as well. ${ }^{113}$ However, this criticism was largely underestimated. ${ }^{114}$

\subsubsection{JCE as a Form of Commission: Why Aiding/Abetting to Specific Intent Crimes is Possible?}

The main argument has been expressed in favour of applicability of JCE III for specific intent crimes that JCE III, like other modes of liability - aiding/abetting, etc. - can be applicable for specific intent crimes with the reduced actus reus and mens rea. ${ }^{115}$ If aiding/abetting genocide is possible, there should be no problem of committing genocide under JCE III. ${ }^{116}$

This argument cannot be sustained because, unlike other modes of liability - aiding/abetting, superiors' liability, JCE III is a form of commission and by that is equated to the physical perpetration. As was mentioned above, it attracts the highest liability together with physical perpetration. As for the liability of a physical perpetrator both actus reus and mens rea should be satisfied, the same applies for JCE III. However, the actus reus for the crime under JCE liability constitutes a

\footnotetext{
${ }^{111}$ Kvočka et al. Appeal Judgement, paras. 259, 261.

112 If the mens rea for murder is reduced to dolus eventualis, the crime can be downgraded to manslaughter. See also Farhang, supra note 90, p. 157; Cassese (2007), supra note 7, p. 120.

${ }^{113}$ See also Ohlin, supra note 20, pp. 710-711, who although conflating 'specific intent' as understood in common law with 'specific intent' as understood in international criminal law, seems to suggest a similar conclusion; see also Olasolo, supra note 11, p. 284.

${ }^{114}$ Despite the STL Appeals Chamber considered that JCE III liability should not apply to specific intent crimes because it would downgrade mens rea from dolus specialis to dolus eventualis (paras. 248-249), it saw no problem in downgrading murder mens rea from dolus directus to dolus eventualis (see para. 244). See also Cassese (2007), supra note 7, arguing that JCE III should not apply to specific intent crimes due to 'logical impossibility' (p. 121) and serious violation of 'personal culpability' and 'causation' principles (p. 122), but allowing the possibility of JCE III to apply to such crimes as murder due to public policy and other reasons (p. 117-118).

115 Brđanin Appeal Decision, para. 7.

${ }^{116}$ Ibid.
} 
combination of all actions of the JCE group. At the same time, the mens rea should be common and complete for the second crime as well. ${ }^{117}$ Otherwise, the conviction of a person under JCE III as a form of commission equated to the physical perpetration would be unprecedented as a person would be e.g. committing genocide satisfying neither the mens rea, nor actus reus of it, in clear violation of principles of personal culpability and fair labelling. ${ }^{118}$

JCE III liability is possible in those circumstances only for certain crimes - the crimes for which the mens rea standard can be dolus eventualis or recklessness. If it is higher than that, the JCE III artificially reduces the mens rea threshold for convictions of commission. That would also make no sense because then, for some of the crimes (where dolus eventualis is a possible mens rea requirement), the full mens rea under JCE III liability will be satisfied, whereas for other crimes (where dolus directus or dolus specialis is the requirement), only partial mens rea will be satisfied. That would make the culpability for different crimes inconsistent, whereas the liability would stay the same.

\subsubsection{Trying to Reconcile Culpability/Liability Mismatch: Liability for Two Crimes under JCE III?} The argument can be put forward that the culpability of the defendant for JCE III crime is reinforced by their participation in JCE itself and their contribution to furthering criminal purpose. If the person decided to participate in a common criminal purpose, they should bear all the consequence of their participation. $^{119}$

This argument conflates two crimes - the first crime (which is part of the JCE purpose) (e.g. forcible transfer) and the second, foreseeable crime (e.g. murder). When charged under JCE III, a person is charged only with murder and not forcible transfer under JCE III. He or she may also be charged under a separate count with JCE I for forcible transfer. If the person is found guilty of both forcible transfer and murder, they will be punished for both of the offences. However, if the argument is to be followed, the person would be punished twice for the same offence - forcible transfer - first time under JCE I as a separate crime, and second time as a part of the murder conviction under JCE III. This arises because the murder conviction would take into account his or her participation and intent in forcible transfer. This situation contradicts the principle ne bis in idem that the person cannot be prosecuted or punished twice for the same conduct. Therefore, despite the suggestion, the liability for JCE III crime should not take into account the culpability for the common criminal purpose crime.

\footnotetext{
117 See also Guistiniani, supra note 62, p. 440.

118 See Robinson, supra note 11, pp. 941-942.

119 See also Cassese and others (2009), supra note 7, p. 326.
} 
If the person is not convicted of a JCE I crime (forcible transfer), the JCE III for murder will fail as well. Firstly, if the person is acquitted because the JCE element or his or her participation was not proved, that would automatically negate the conviction of JCE III (as there will be no JCE III). ${ }^{120}$ Secondly, if a person is not convicted under JCE I of a crime, because no such crime happened, the JCE III will collapse as that would render the whole common criminal purpose incomplete. Unlike the crime of conspiracy to genocide (which is a separate crime and exists only for genocide), the JCE as a mode of liability requires the actual commission of the crime. ${ }^{121}$ Therefore, the JCE will fail in its entirety and there will be no fault for the defendant to be blamed for.

Thus, the culpability of the defendant only for the foreseeable crime should be taken into account under JCE III. If advertent recklessness or dolus eventualis can satisfy the mens rea requirement for a particular crime, the defendant can be charged with that crime under JCE III. If the type of crime is such as requires higher mens rea to be satisfied - dolus directus or dolus specialis - the defendant should not be charged with that crime under JCE III, unless such a high level of mens rea can be established. This is so if the status of JCE III liability as the liability for commission is to be maintained.

Both of these possibilities were discussed to a certain extent in the academic literature. Some authors suggested that the full mens rea should be required, when a person is charged with a specific intent crime under JCE III. ${ }^{122}$ In order to implement this solution, JCE III liability would have to either be disregarded (and the persons would be charged with JCE I instead) or adjusted to reflect higher mens rea of some crimes. In this way, the level of culpability of the person convicted under JCE III would be increased by imposing higher mens rea standards (although actus reus would remain the same). That would at least partially address the issue of the mismatch of liability and culpability by raising the level of culpability to reflect the high degree of liability.

A similar approach suggests that JCE III is not applicable to specific intent crimes, as it is logically impossible to reconcile the low standard of mens rea required under JCE III and the high mens rea threshold for specific intent crimes. ${ }^{123}$ In this way, a person would be either charged with aiding/abetting to a specific intent crime, or with a lesser crime (not requiring specific intent crime to be proved) under JCE III. ${ }^{124}$ This approach seems to impose a limit on the application of JCE III to certain crimes. It may be more difficult to follow this approach given that the decision to charge a

\footnotetext{
${ }^{120}$ See Gotovina Appeal Judgement, para. 97.

${ }^{121}$ Tolimir Appeal Judgement, para. 590.

122 See J. Stewart, 'The end of 'modes of liability' for international crimes,' 25 Leiden Journal of International Law 165 , pp. 177-178, who argues that not only JCE III but also other modes of liability must require the same subjective standards as required for each particular crime. Otherwise, 'modes of liability warp responsibility as distinct from merely attributing wrongdoing in line with the moral weight of the crime in question.'

${ }^{123}$ See Cassese (2007), supra note 7, p. 121.

124 See Cassese (2007), supra note 7, pp. 122, 133.
} 
person with a particular crime under a particular mode of liability is taken by the prosecution, not by the Chamber. Furthermore, excluding the application of a particular mode of liability (JCE III) to some crimes only may conflate the distinction between modes of liability and the crimes committed. Other authors took the approach that in order to reconcile the reduced mens rea required to prove the extended crime under JCE III with specific intent crimes, JCE III would be considered not a form of commission, but a form of 'participation,' or 'accomplice liability', akin aiding/abetting, which does not require proof of the full mens rea for specific intent crimes, unlike 'perpetration'. ${ }^{125}$ This solution would require the Chambers to adopt different terminology, when discussing JCE III liability and avoid the word 'committed' being attached to it. The sentencing principles would also need to be reconsidered to reflect this change. By that, the degree of liability could be reduced to match the level of culpability of the defendants.

\section{Conclusion}

Analysis confirms the main contention of this article that the level of culpability does not coincide with the degree of liability under JCE III. The liability is much higher than the level of culpability of a person who is deemed to have 'committed' the crime in question.

This situation can lead to serious consequences from generating a sense of injustice of those who are convicted under JCE III to undermining the fairness of the trials by the International Tribunals and their authority. It also creates potentially disproportionate punishment for a low level of culpability. While the degree of harm caused by the crime committed can be very high, the level of culpability will be low.

The expansion of the JCE doctrine to include the perpetration of the crimes by non-members further blurred the link between the defendants and actual perpetration of the crimes. This is especially so for JCE III where the crimes physically perpetrated by non-members were never intended by the defendant (only foreseen). This may create paradoxical situations where the causation is difficult to prove but the liability still follows from the actions not even related to the commission of the crime charged (when a significant contribution was made to the commission of common purpose crime, not a foreseeable crime). The defendant may not even be aware of the involvement of the non-members in the commission of the foreseen crimes.

The application of JCE III is particularly problematic in relation to the specific intent crimes, as it differentiates the level of culpability and degree of liability even further due to lowering the standard

\footnotetext{
${ }^{125}$ On this point, see van Sliedregt (2007), supra note 13, pp. 201, 203. 205; Olasolo, supra note 11, pp. 286-287. Ohlin goes even further to propose to divide JCE into two modes of liability: 'co-perpetrating by JCE' and 'aiding and abetting a JCE' liability (meaning probably a form of accessorial liability) to address the problem of the application of JCE to specific intent crimes (see Ohlin, supra note 20, p.710).
} 
of mens rea required to be proved. A specific intent crime may now be 'committed' with only basic intent - recklessness or dolus eventualis.

All these factors make the level of culpability for a particular crime lower than the degree of liability under JCE III, which is one of the highest (as it is the liability for commission). The JCE III liability becomes artificially constructed. A person may be convicted of something they have not committed. The sense of injustice will follow the JCE III liability unless it is rectified and its expansion pushed back by the subsequent jurisprudence to eliminate the discrepancies highlighted by this article. The necessary changes to the JCE doctrine should be made to provide more legitimacy to the doctrine and ICTY jurisprudence as a whole.

One of the potential solutions would be to remove at least 'JCE III' liability from the liability for 'commission' and impose a sentence lower than for other modes of liability for commission. That would mean that the liability would become of a lower degree to what it stands now and would better match the level of culpability. An alternative change would be to raise the degree of required culpability by increasing the threshold of mens realactus reus by requiring a more serious contribution to the commission of the second, foreseeable, crime, and by raising the mens rea standard to match the one required by the crime (in case specific intent crimes that would be dolus specialis). That would ensure that the culpability of persons convicted under JCE III would better match the high degree of liability and sentence attached to it. This would also make the ICTY's legacy conform better to the interests of justice and serve as a better example for the progressive development of international criminal law. 